\title{
Case-control study of HLA-G promoter methylation status, HPV infection and cervical neoplasia in Curitiba, Brazil: a pilot analysis
}

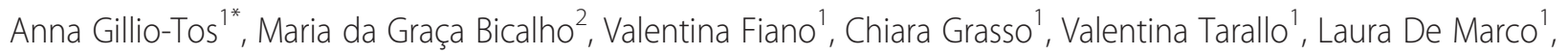
Morena Trevisan', Marina Barbara de Sousa Xavier ${ }^{2}$, Renata Slowik², Newton S Carvalho ${ }^{3}$, Carlos A Maestri ${ }^{4}$, Hadriano M Lacerda', Daniela Zugna ${ }^{1}$, Lorenzo Richiardi ${ }^{1,5}$ and Franco Merletti ${ }^{1,5}$

\begin{abstract}
Background: The causal association between persistent human papillomavirus (HPV) infection and cervical cancer has been established, but the mechanisms that favor HPV persistence in cervical cells are still unknown. The diminished capability of the immune system to control and resolve HPV infection is one of several hypotheses. The tolerogenic protein HLA-G has shown aberrant expression in a variety of cancers, which has been suggested as a mechanism for tumor escape from immunosurveillance. In the present study we evaluate the role of epigenetic modification (promoter de-methylation) of the HLA-G gene on susceptibility to HPV infection and development of high-grade cervical lesions.

Methods: A case-control study was carried out in Curitiba, Brazil, between February and June 2010. A total of 789 women aged 15-47 years were recruited: 510 controls with normal cervical cytology, and 279 cases with histologically confirmed cervical intraepithelial neoplasia grade $2(C I N 2, N=150)$ or grade $3(C I N 3, N=129)$. All women were administered a questionnaire by interview, which collected information on demographic and lifestyle factors, and a cervical sample was collected. HPV DNA detection was performed by GP5+/GP6+ primer-mediated PCR. HPV-positive samples were genotyped by multiplex PCR. A pilot analysis of HLA-G promoter methylation was carried out in a subset of the study population (96 cases and 76 controls) by pyrosequencing. HLA-G methylation and HPV infection status of cases and controls were compared, and confounding factors were computed by $t$ Student and non-parametric Wilcoxon tests. Comparison of HLA-G methylation between cases and controls was assessed by the Bonferroni correction. The association of HLA-G methylation with CIN2/3 was evaluated by logistic regression.
\end{abstract}

Results: HPV prevalence was 19.6\% in controls and 94.3\% in CIN2/3 cases. HPV16, 31, 33, 35 and 18 were the most prevalent types. Methylation analysis of seven CpGs in the HLA-G promoter did not reveal any spontaneous de-methylation events in CIN2/3 cases (mean proportion of methylation: 75.8\%) with respect to controls (mean 73.7\%; odds ratio 1.01, 95\% confidence interval 0.96, 1.07).

Conclusions: This study did not support the hypothesis that spontaneous de-methylation events in the HLA-G promoter play a primary role in promoting escape from immunosurveillance in the development of precancerous cervical lesions.

Keywords: HPV, Cervical cancer, HLA-G, Methylation

\footnotetext{
* Correspondence: gilliotos.demarco@cpo.it

${ }^{1}$ Department of Medical Sciences, Unit of Cancer Epidemiology - C.E.R.M.S,

University of Turin, Turin, Italy

Full list of author information is available at the end of the article
} 


\section{Background}

Cervical cancer is the third most common cancer and the fourth cause of cancer mortality in women worldwide [1]. Screening programs in industrialized countries have drastically reduced the incidence and mortality of cervical cancer, and research in the last decades has greatly improved our capability to detect the etiologic viral component of the disease, human papillomavirus (HPV), and contributed to a decrease in rates of progression to cervical cancer.

Nevertheless, cervical cancer remains a public health issue. Several unresolved aspects of the natural history of the disease also remain. Among these is the mechanism behind the development of cervical cancer. Indeed, only a small proportion of women infected with HPV ever develop cervical cancer; in most women the infection regresses spontaneously. While the causal association between persistence of HPV infection and risk of developing cervical lesions is recognized [2], the events that promote or prevent this persistence in cervical cells has not yet been identified. Several hypotheses exist, one of which is the capability of the immune system to control and resolve HPV infection. One recently considered hypothesis focuses on human leucocyte antigen-G (HLA-G), a tolerogenic protein involved in the control of immune response, due to its reported aberrant expression in a wide variety of cancer cells [3-6]. HLA-G is a non-classical gene of the major hystocompatibility complex that codes for a protein involved in immunosuppressive mechanisms. HLA-G inhibits cell-mediated immunity through interaction with receptors expressed on lymphoid, myeloid and natural killer cells [7,8]. It plays a primary role in immune tolerance, and has been widely described in fetal-maternal tolerance [9]. The HLA-G protein is physiologically present in fetal [10] and immature (thymus [11]) cells, and in a small number of adult tissues [5,11-13], but it is not commonly expressed in mature normal cells. HLA-G re-expression has been suggested as a mechanism of viral [14] and tumor [3-6] escape from immunosurveillance. Recent evidence [15] showed that HLA-G expression increased with grade of precancerous cervical lesions, with the highest expression found in cervical cancer. Since promoter methylation has been described as one of the crucial mechanisms that regulate gene expression [16], occurrence of spontaneous de-methylation events in the HLA-G promoter was postulated to explain the reexpression of this protein in adult cells. De-methylation events have been reported in the HLA-G promoter of ovarian tumor cells compared to normal ovarian epithelial cells [17].

The present study aimed to investigate the association of HPV infection and development of cervical intraepithelial neoplasia grades 2 (CIN2) and 3 (CIN3) with
HLA-G promoter methylation in a Brazilian population. Association with the characteristics of the study population was also evaluated.

\section{Materials and Methods Study population and sample collection}

A case-control study was set up in the framework of the collaboration among the Unit of Cancer Epidemiology in Turin, Italy; the Laboratory of Immunogenetics and Hystocompatibility (LIGH) in Curitiba, Brazil; the Department of Gynecology and Obstetrics, at the Federal University of Paraná, Infectious Diseases in Gynecology and Obstetrics Sector; and the Department of Cervical Pathology, Hospital Erasto Gaertner, in Curitiba, Brazil. The study was approved by the Ethical Committee for Clinical Research of the Hospital Erasto Gaertner (protocol CEP: 81520-060, P.P No 1943). All participating women were informed about the study purpose and signed an informed consent form.

Women were recruited in Curitiba, where the prevalence of HPV infection and cervical lesions has been reported to be higher than in Turin [18-20]. Under the supervision of the LIGH, women aged 15 to 47 years were recruited: local gynecologists working at three reference centers for cervical cancer screening collaborated to enroll women. Some women were also recruited through awareness campaigns for adhesion to cervical screening. Women over 47 years of age were not included to avoid atrophy or dysplasia associated with menopause, although the suggested impact of menopausal hormonal status on cervical dysplasia due to a weakened immune response, specifically in HPV-positive menopausal women, has not been properly documented.

A total of 789 women were recruited: 510 had normal cervical cytology and were classified as controls; 279 had histologically confirmed CIN2 $(\mathrm{N}=150)$ or CIN3 $(\mathrm{N}=$ 129) after loop electrosurgical excision procedure or cold knife conization, and were classified as CIN2/3 cases. A cervical sample was collected from all study women. Cervical cell samples were collected from controls at collection for cytology using the cytobrush provided in the collection kit (Digene sample collection kit, Qiagen, Hilden, Germany), which was then placed into a tube containing sample transport medium (STM, Qiagen). A cervical sample was analogously collected in STM from CIN2/3 cases at loop electrosurgical excision procedure or cold-knife conization.

Study women were administered a questionnaire by interview, which collected information on demographic, sexual and lifestyle factors, including age, education level, ethnic group, age at first sexual intercourse, lifetime number of sexual partners, number of full-term pregnancies, smoking status and number of cigarettes smoked per day. Study women were classified into four 
ethnic groups based on their replies in the questionnaire: Euro-Descendent, Afro-Descendent, Brazilian Mixed and Asian. There is a general consensus as to the definition of a person of Brazilian Mixed ethnicity in the Genetic Department of the Federal University of Paranà in Curitiba, and following that consensus, all study women with a multiracial origin, i.e., a miscegenation of Euro-Descendent (mostly), Afro-Descendent, Amerindian and East Asian, were classified as Brazilian Mixed [21]. Women were assigned to the corresponding ethnic group following interview at recruitment.

\section{DNA extraction}

Genomic DNA was extracted from cervical cell samples using the commercial purification system QIAmp DNA Mini Kit (Qiagen) according to the manufacturer's instructions. The final elution in $100 \mu \mathrm{l}$ of the provided elution buffer was repeated twice to increase the DNA yield. The DNA concentration was evaluated by a Nanodrop spectrophotometer (Thermo Scientific, Wilmington, DE, USA). DNA adequacy was checked by amplification of a $\beta$-globin housekeeping gene sequence of $268 \mathrm{bp}$, as previously described [22]. After gel electrophoresis onto a $2 \%$ agarose gel stained with ethidium bromide, amplicons were visualized by ultraviolet trans-illumination. The amplicon of the $\beta$-globin gene fragment was detected in all the study samples. Purified DNA was stored at $-80^{\circ} \mathrm{C}$.

\section{HPV detection}

HPV detection was performed in Turin, Italy, on the genomic DNA extracted from cervical samples by consensus primer GP5+/6+-mediated PCR [23], which allows to detect a broad variety of HPV types. PCR reaction was performed in a total volume of $25 \mu \mathrm{l}$ containing buffer $(\mathrm{KCl}) 50 \mathrm{mM}$, Tris-HC1 $10 \mathrm{mM}$ pH 8.3, dNTP $200 \mu \mathrm{M}, \mathrm{MgCl}_{2} 3.5 \mathrm{mM}$, Taq polymerase $1 \mathrm{U}, \mathrm{GP} 5+/ 6+$ $50 \mathrm{pmol}$ and DNA $5 \mu \mathrm{l}$. The following amplification profile was used: $94^{\circ} \mathrm{C}$ for $9 \mathrm{~min}$, followed by 40 cycles of denaturation at $94^{\circ} \mathrm{C}$ for $20 \mathrm{~s}$, annealing at $38^{\circ} \mathrm{C}$ for $30 \mathrm{~s}$, extension at $71^{\circ} \mathrm{C}$ for $80 \mathrm{~s}$. A final extension of $4 \mathrm{~min}$ at $71^{\circ} \mathrm{C}$ was performed.

\section{HPV genotyping}

HPV-positive samples were genotyped by multiplex PCR, in order to detect the seven oncogenic HPV types that are prevalent, and more associated with cervical cancer in Brazil [24]: HPV16, 18, 31, 33, 35, 45 and 52. Multiplex PCR was performed as previously described [25], with the exception of HPV16, for which a different primer set was used [26]. Briefly, the PCR mix was carried out in a final volume of $25 \mu$ containing buffer (KCl) $1 \mathrm{X}, \mathrm{MgCl}_{2} 2 \mathrm{mM}$, dNTPs $200 \mu \mathrm{M}, 0.4 \mu \mathrm{M}$ both primers, Taq polymerase $2.5 \mathrm{U}$, and DNA $3 \mu \mathrm{l}$. The amplification profile was as follows: $94^{\circ} \mathrm{C}$ for $4 \mathrm{~min}$, followed by 35 cycles of denaturation at $94^{\circ} \mathrm{C}$ for
$30 \mathrm{~s}$, annealing at $56^{\circ} \mathrm{C}$ for $30 \mathrm{~s}$, extension at $72^{\circ} \mathrm{C}$ for $45 \mathrm{~s}$. A final extension at $72^{\circ} \mathrm{C}$ for $4 \mathrm{~min}$ was performed.

The set of primers used for the multiplex PCR were as follows: HPV16 sense $5^{\prime}$ AAGGGCGTAACCGAAATCGG T3', antisense 5'CATATACCTCACGTCGCAG3'; HPV18 sense $5^{\prime}$ CACTTCACTGCAAGACATAGA3' ${ }^{\prime}$, antisense $5^{\prime} \mathrm{G}$ TTGTGAAATCGTCGTTTTTCA3';

HPV31 sense 5'GAAATTGCATGAACTAAGCTCG3', antisense 5'ACATATACCTTTGTTT-GTCAA3'; HPV33 sense 5'ACTATACACAACATTGAACTA3', antisense 5'GTTTTTACACG-TCACAGTGCA3'; HPV35 sense 5'CAACGAGGTAGAAAGC-ATC3', antisense 5'CCGACCTG TCCACCGTCCACCG3'; HPV45 sense 5GATG GAAAAGTGCATTACAGG3, antisense 5'ACCTCTGTG CGTTCCAATGT3 ${ }^{\prime}$;HPV52 sense 5'TAAGGCTG CAGTG TGTGCAG3', antisense 5'CTAAT AGTTATTTCACTT AATGGT3'.

Samples positive at HPV detection, but negative at PCR genotyping were re-tested by reverse-line blot hybridization using the Digene HPV Genotyping $\mathrm{RH}$ (Qiagen) commercial kit, according to the manufacturer's protocol. The kit employed biotynilated primers (GP5+/GP6+) and the assay targets 18 HPV types [27], including those classified by the International Agency for Research on Cancer (IARC) as carcinogenic (Group 1 carcinogen, HPV16, 18, 31, 33, 35, 39, 45, 51, 52, 56, $58,59)$, probably carcinogenic (Group 2A carcinogen, HPV68), and as possibly carcinogenic to humans (Group 2B carcinogen, HPV26, 53, 66, 73, 82) [28]. PCR biotinylated products $(10 \mu \mathrm{l})$ were denatured and hybridized with type-specific oligonucleotide probes immobilized as parallel lines on nitrocellulose membrane strips. The hybrids were detected with alkaline phosphatase-streptavidin conjugate and substrate (5-bromo-4-chloro-3-indolylphosphate and nitroblue tetrazolium), resulting in a purple precipitate at positive probe lines. After drying, the strips were analyzed by visually comparing them with the interpretation grid supplied in the kit; the presence of a clearly visible line was considered a positive reaction.

A biotinylated poly (dT) control for conjugate reaction was applied to each strip to ensure the validity of the test and proper alignment of the strips on the interpretation sheet.

\section{HLA-G methylation - pilot analysis}

The analysis of the HLA-G methylation was performed as a pilot analysis on the first set of samples shipped to Italy from Brazil ( $\mathrm{N}=172,76$ controls and $96 \mathrm{CIN} 2 / 3$ cases). The analysis was performed through bisulfite modification and pyrosequencing

\section{Bisulfite modification}

Sodium bisulfite modification converts unmethylated cytosine into uracyl, but leaves the methylated cytosines 
unchanged. Genomic DNA $(1 \mu \mathrm{g})$ from cervical samples was converted using the EpiTect Bisulfite commercial kit (Qiagen) according to the manufacturer's instructions.

\section{Pyrosequencing}

Pyrosequencing was used to evaluate HLA-G methylation status and to quantify the methylation of each individual CpG investigated. It was performed on a Pyromark Q24 using PyroMark Gold Q24 (Qiagen) reagents. The assay allowed the quantification of methylation of the seven CpGs we sited in the HLA-G promoter, using primers designed with the Pyromark Assay Design software (Qiagen) according to the HLA-G reference sequence GenBank J03027.1. Preliminary PCR was performed, targeting a $441 \mathrm{bp}$ sequence of the HLA-G promoter, using primers with the following sequences: sense 5'GGGAGGTAGGGAGTTTAGTT-TA3', antisense Biotin5'CCATAACCACCATCCTTAAC3'. The primer antisense is biotinylated to allow binding to sepharose beads during the subsequent pyrosequencing process. To improve efficiency, three different pairs of sequencing primers that targeted 2, 3 and 2 CpGs, respectively, were employed: Sequencing primer 1 (2 CpGs, positions 350 and 428) 5'GGAGTTTAGTTTAGGGATAG3', Sequencing primer 2 (3 CpGs, positions 494, 512 and 523) 5'ATTTAG GGAGATATTGAGA3', Sequencing primer 3 (2 CpGs, positions 573 and 598) 5'GGGTTTTAGGTTTTATAGG3'.

The preliminary PCR reaction was performed in a total volume of $35 \mu \mathrm{l}$ containing buffer $(\mathrm{KCl}) 1 \mathrm{X}, \mathrm{MgCl}_{2}$ $2 \mathrm{mM}$, dNTPs $200 \mu \mathrm{M}, 0.5 \mu \mathrm{M}$ each primer (antisense biotinylated), Taq polymerase $1.75 \mathrm{U}$ and $6 \mu \mathrm{l}$ converted DNA with the following cycling profile: $95^{\circ} \mathrm{C}$ for $1 \mathrm{~min}$ followed by 45 denaturation cycles at $54^{\circ} \mathrm{C}$ for $1 \mathrm{~min}$, annealing at $56^{\circ} \mathrm{C}$ for $1 \mathrm{~min}$, extension at $72^{\circ} \mathrm{C}$ for $1 \mathrm{~min}$, final extension at $72^{\circ} \mathrm{C}$ for $10 \mathrm{~min}$. Amplicons were analyzed by gel electrophoresis on a $2 \%$ agarose gel stained with ethidium bromide and visualized by ultraviolet trans-illumination. The residual PCR product $(28 \mu \mathrm{l})$ was added to $12 \mu \mathrm{l}$ of $\mathrm{dH}_{2} \mathrm{O}$ and incubated under shaking with $37 \mu \mathrm{l}$ of binding buffer $\mathrm{pH} 7.6(10 \mathrm{mM}$ Tris-HCl; $2 \mathrm{M} \mathrm{NaCl} ; 1 \mathrm{mM}$ EDTA; 0.1\% Tween 20) and $3 \mathrm{ml}$ sepharose beads covered with streptavidin. PCR products were washed with ethanol $70 \%$, denatured with $\mathrm{NaOH} 0.2 \mathrm{M}$ and re-washed with Tris-Acetate $10 \mathrm{mM}$ $\mathrm{pH}$ 7.6. Pyrosequencing reaction was performed in $45 \mu \mathrm{l}$ of annealing buffer [44.82 $\mu \mathrm{l}$ of $20 \mathrm{mM}$ Tris-Acetate + $5 \mathrm{mM} \mathrm{MgAc}_{2}$ and $0.18 \mu \mathrm{l}$ of sequencing primer $(0.3 \mu \mathrm{M})]$.

Quantitative methylation results were expressed as the mean of the methylation percentage of all seven CpGs investigated.

The individual methylation percentage for two CpGs, one located in a binding site for the transcription factor specificity protein 1 ( $\mathrm{Sp} 1$ ), and the other located in the enhancer region, were also evaluated for their association with HPV infection and CIN2/3.

\section{Statistical analyses}

Analyses investigating the association between HLA-G methylation, HPV status, and demographic and lifestyle factors were restricted to controls, due to the fact that almost all CIN2/3 cases were HPV-positive. For HLA-G methylation analyses with sufficiently high frequency, the $t$ Student test was used, or alternatively the nonparametric Wilcoxon test. To evaluate whether there was a difference in the percentage of methylation between CIN2/3 cases and controls, and to further compare subgroups of the study population (i.e., controls vs. CIN2 cases, controls vs. CIN3 cases, CIN2 cases vs. CIN3 cases), the Bonferroni correction for multiple comparisons was used. Logistic regression models, adjusted for age, education level, ethnic group and smoking status, were fitted to evaluate the effect of HLA-G methylation on the development of cervical cancer [crude and adjusted odds ratios (ORs) are reported].

\section{Results}

\section{Characteristics of the study population}

During the study period 789 women were recruited, including 510 controls and 279 CIN2/3 cases (150 CIN2, 129 CIN3). CIN2/3 cases and controls had a comparable mean age (32 years for both), education level, age at first sexual intercourse (16 years for cases, 17 years for controls) and number of full-term pregnancies (Table 1). The ethnic group Brazilian Mixed showed the highest prevalence of HPV infection in both CIN2/3 cases and controls. Slight differences emerged in the distribution of $\mathrm{CIN} 2 / 3$ cases and controls by ethnic group, sexual factors, and smoking status. The most represented ethnic group in CIN2/3 cases was Brazilian Mixed (58.1\%), while in controls it was Euro-Descendent (46.9\%). Among CIN2/3 cases, $74.6 \%$ reported a total number of partners between 2 and 10, while the corresponding percentage among controls was $53.9 \%$. Current smokers were more common among CIN $2 / 3$ cases (34.4\%) than controls (15.9\%) (Table 1).

\section{HPV detection and type distribution}

We found a HPV prevalence of $19.6 \%$ in controls and 94.3\% in CIN2/3 cases (Table 2). HPV-positive CIN2/3 cases and controls showed a higher frequency of single HPV infections (cases 66.2\%, controls 65\%) than multiple infections (cases $32.7 \%$, controls $29 \%$ ). A proportion of samples could not be typed (cases $1.14 \%$, controls $6 \%$ ) by our methods. Among the most frequent genotypes (HPV16, 18, 31, 33, 35, 45 and 52, IARC Group 1 carcinogen [28]) a higher prevalence was observed for 
Table 1 Characteristics of the study population

\begin{tabular}{|c|c|c|c|c|}
\hline & & & Controls & \\
\hline & $\mathrm{N}$ & $\%$ & $N$ & $\%$ \\
\hline Number & 279 & & 510 & $100 \%$ \\
\hline Controls (normal cytology) & - & & 510 & \\
\hline CIN2 & 150 & 53.7 & - & \\
\hline CIN3 & 129 & 46.3 & - & \\
\hline Mean age & 32 years & & 32 years & \\
\hline Range & $15-47$ & & $15-47$ & \\
\hline \multicolumn{5}{|l|}{ Education level } \\
\hline Elementary school & 164 & 58.8 & 262 & 51.4 \\
\hline Middle school & 93 & 33.3 & 159 & 31.2 \\
\hline High school & 8 & 2.9 & 18 & 3.5 \\
\hline Missing & 14 & 5.0 & 71 & 13.9 \\
\hline \multicolumn{5}{|l|}{ Ethnic group } \\
\hline Euro-Descendent & 90 & 32.3 & 239 & 46.9 \\
\hline Afro-Descendent & 7 & 2.5 & 24 & 4.7 \\
\hline Brazilian Mixed* & 162 & 58.1 & 180 & 35.3 \\
\hline Asian & 1 & 0.4 & 1 & 0.2 \\
\hline Missing & 19 & 6.8 & 66 & 12.9 \\
\hline Age at first sexual intercourse & & 16 years & & 17 years \\
\hline \multicolumn{5}{|l|}{ Lifetime number of sexual partners } \\
\hline 1 & 42 & 15.0 & 156 & 30.6 \\
\hline $2-10$ & 208 & 74.6 & 275 & 53.9 \\
\hline$>10$ & 27 & 9.7 & 79 & 15.5 \\
\hline Missing & 2 & 0.7 & 0 & 0 \\
\hline Number of full-term pregnancies & 2 & & 2 & \\
\hline Range & $0-18$ & & $0-27$ & \\
\hline \multicolumn{5}{|l|}{ Smoking status } \\
\hline Never smoker & 130 & 46.6 & 277 & 54.3 \\
\hline Former smoker & 51 & 18.3 & 148 & 29.0 \\
\hline Number of cigarettes/day (mean) & 7 & & 8 & \\
\hline Current smoker & 96 & 34.4 & 81 & 15.9 \\
\hline Number of cigarettes/day (mean) & 7 & & 8 & \\
\hline Missing & 2 & 0.7 & 4 & 0.8 \\
\hline
\end{tabular}

*Brazilian Mixed: Mixed ethnicity with Euro-Descendent (mostly), Afro-Descendent, Amerindian and East Asian.

HPV16, 31 and 33 for both CIN2/3 cases and controls, followed by HPV35, 52, 18 and 45 in CIN2/3 cases, and HPV18, 35, 52 and 45 in controls (Table 3). A cumulative frequency of $9.3 \%$ and $4.9 \%$ was detected in CIN2/ 34 cases and controls respectively, for HPV types with a lower prevalence: HPV39, 51, 56, 58 and 59, IARC Group 1 carcinogen; HPV68, IARC Group 2A carcinogen; and HPV26, 53, 66, 73 and 82, IARC Group 2B carcinogen [28].
Frequency of HPV infection by selected characteristics in controls

Table 4 reports the frequency of HPV infection by selected characteristics among controls. HPV infection was inversely associated with age $(\mathrm{p}<0.001)$, and was positively associated with lifetime number of sexual partners $(\mathrm{p}=0.001)$, smoking status $(\mathrm{p}=0.09)$ and Brazilian Mixed ethnic group ( $p=0.09)$. There was no evidence of association with education level $(\mathrm{p}=0.31)$. 
Table 2 Frequency of human papillomavirus (HPV) infection in the study population

\begin{tabular}{|c|c|c|c|c|}
\hline & \multirow{2}{*}{\multicolumn{2}{|c|}{$\begin{array}{c}\text { Cases } \\
\mathrm{N}=\mathbf{2 7 9}\end{array}$}} & \multirow{2}{*}{\multicolumn{2}{|c|}{$\begin{array}{l}\text { Controls } \\
\mathrm{N}=510\end{array}$}} \\
\hline & & & & \\
\hline & $\mathbf{N}$ & $\%$ & $\mathrm{~N}$ & $\%$ \\
\hline HPV- & 16 & 5.7 & 410 & 80.4 \\
\hline HPV+ & 263 & 94.3 & 100 & 19.6 \\
\hline Single infections & 174 & 66.2 & 65 & 65.0 \\
\hline Multiple infections & 86 & 32.7 & 29 & 29.0 \\
\hline Not typed by our methods & 3 & 1.14 & 6 & 6.0 \\
\hline
\end{tabular}

HLA-G methylation status - pilot analysis

We calculated the mean percentage of methylation of the seven evaluated CpGs of the HLA-G promoter, among the 76 controls and 96 CIN2/3 cases included in the pilot analysis. We did not find lower methylation levels among CIN2/3 cases as expected, instead they were slightly higher (Table 5). Demographic and lifestyle factors, specifically smoking status and ethnicity, were not associated with mean HLA-G methylation (data not shown). Moreover, no decrease was found in overall methylation when HPV-positive and HPV-negative controls were compared (data not shown).

The CpGs located in regulatory sites of the HLA-G promoter, i.e., the binding site for the transcription factor Sp1 (sequence position 573), and the enhancer region (sequence position 598), were also evaluated individually with the aim of highlighting any relevant decrease in methylation that could directly affect gene transcription. The results, stratified for HPV positivity in controls, and for CIN2 and CIN3 in cases, are shown in Table 6. There was no evidence of any differences in the mean methylation percentage between CIN2/3 cases and controls for the CpG located in

Table 3 Distribution of selected human papillomavirus (HPV) types in the study population

\begin{tabular}{|c|c|c|c|c|}
\hline \multirow[t]{3}{*}{ High-risk HPV types $^{\S}$} & \multirow{2}{*}{\multicolumn{2}{|c|}{$\begin{array}{c}\text { Cases } \\
\mathrm{N}=\mathbf{2 7 9}\end{array}$}} & \multirow{2}{*}{\multicolumn{2}{|c|}{$\begin{array}{l}\text { Controls } \\
\mathrm{N}=510\end{array}$}} \\
\hline & & & & \\
\hline & $\mathrm{N}$ & $\%$ & $\mathrm{~N}$ & $\%$ \\
\hline HPV16 & 17161.3 & 61.3 & 38 & 7.4 \\
\hline HPV18 & 217.5 & 7.5 & 9 & 1.8 \\
\hline HPV31 & 5017.9 & 17.9 & 16 & 3.18 \\
\hline HPV33 & 3111.1 & 11.1 & 12 & 2.38 \\
\hline HPV35 & 279.7 & 9.7 & 8 & 1.6 \\
\hline HPV45 & 134.7 & 4.7 & 6 & 1.2 \\
\hline HPV52 & 248.6 & 8.6 & 7 & 1.4 \\
\hline Less frequent HPV types* & 26 & 9.3 & 25 & 4.9 \\
\hline
\end{tabular}

${ }^{\S} \mathrm{HPV}$ types present in single or multiple infections.

* Includes IARC Group 1 carcinogen types HPV39, 51, 56, 58, 59; Group 2A carcinogen type HPV 68; and Group 2B carcinogen types HPV26, 53, 59, 66, $73,82$.
Table 4 Frequency of HPV infection by characteristics of controls

\begin{tabular}{lcc}
\hline & \multicolumn{2}{c}{ CONTROLS } \\
\cline { 2 - 3 } & \multicolumn{2}{c}{$\mathbf{N = 5 1 0}$} \\
\cline { 2 - 3 } & HPV+/N & \\
\hline Age (years) & & \\
$<25$ & $36 / 101$ & 35.64 \\
$25-34$ & $40 / 201$ & 19.90 \\
$35-44$ & $22 / 187$ & 11.76 \\
$\geq 45<25$ & $2 / 21$ & 9.52 \\
Education level & & \\
Elementary school & $57 / 261$ & 21.84 \\
Middle school & $27 / 159$ & 16.98 \\
High school & $2 / 18$ & 11.11 \\
Ethnic group & & \\
Euro-Descendent & $39 / 239$ & 16.32 \\
Afro-Descendent & $4 / 24$ & 16.67 \\
Brazilian Mixed* & $47 / 180$ & 26.11 \\
Asian & $0 / 1$ & 0
\end{tabular}

Lifetime number of sexual partners

$\begin{array}{lcc}1 & 16 / 156 & 10.26 \\ 2-10 & 62 / 275 & 22.55 \\ >10 & 22 / 79 & 27.85\end{array}$

Smoking status

Never smoker $\quad 45 / 277 \quad 16.25$

Former smoker $\quad 36 / 148 \quad 24.32$

Current smoker $\quad 19 / 81 \quad 23.46$

*Brazilian Mixed: Mixed ethnicity with Euro-Descendent, Afro-Descendent, Amerindian and East Asian.

the binding site for transcription factor $\mathrm{Sp} 1$ (crude $\mathrm{OR}=$ 1.01, 95\% confidence interval [CI]: 0.97,1.06; adjusted OR = 1.01, 95\% CI: 0.96,1.07), while the mean methylation percentage for the $\mathrm{CpG}$ located in the enhancer region was slightly higher in CIN2/3 cases than in controls (crude OR $=1.04,95 \%$ CI: 1.00,1.08; adjusted OR $=1.03,95 \%$ CI: $0.99,1.08)$. These results were confirmed when the analysis was restricted to HPV-positive controls for both individually analyzed CpGs (binding site for transcription factor

Table 5 Overall mean methylation percentage in the study population

\begin{tabular}{|c|c|c|}
\hline & Cases & Controls \\
\hline & $\mathrm{N}=96$ & $N=76$ \\
\hline & $\overline{\text { (\% Methylation) }}$ & (\% Methylation) \\
\hline \multicolumn{3}{|c|}{7 CpGs* in HLA-G promoter } \\
\hline mean methylation & 75.8 & 73.7 \\
\hline Range & $70-83$ & $71-83$ \\
\hline
\end{tabular}


Table 6 Mean methylation percentage in specific CpG sites

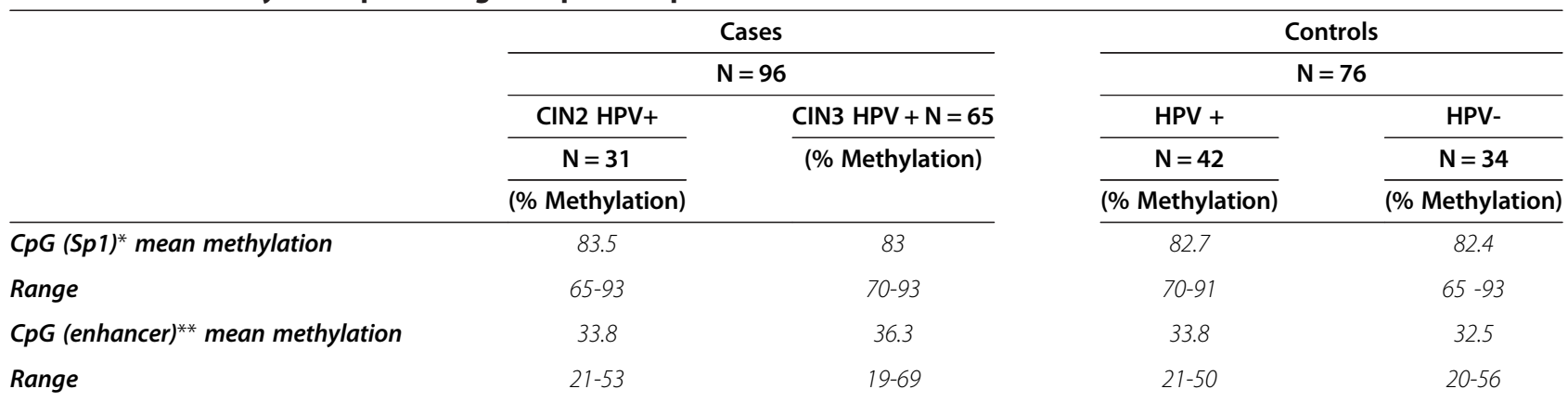

* CpG site position 573; ** CpG site position 598 (GenBank: J03027.1).

Sp1: crude $\mathrm{OR}=1.01,95 \% \mathrm{CI}: 0.96,1.07$; adjusted $\mathrm{OR}=$ 0.99, 95\% CI: 0.93,1.07; enhancer region: crude OR = 1.03, 95\% CI: 0.98,1.08; adjusted OR = 1.01, 95\% CI: 0.95,1.06).

When a threshold of the median percentage of methylation (33\%) was applied for the CpG located in the enhancer region (Table 7$)$, we obtained a higher proportion of CIN2/3 cases (61.5\%) than controls (47.4\%) with methylation levels over the threshold (crude $\mathrm{OR}=1.77$, 95\% CI: 0.96,3.26; adjusted OR = 1.40, 95\% CI: 0.71,2.76).

\section{Discussion}

A case-control study was set up in a Brazilian female population to investigate the relationships between HPV infection, prevalence of HPV types, methylation status in the gene promoter of the tolerogenic HLA-G protein and high-grade cervical lesions.

We explored the occurrence of spontaneous demethylation in the HLA-G promoter as a surrogate of reexpression of the HLA-G protein in HPV-infected cells, as the HLA-G protein is a recognized inducer of a tolerogenic effect and tumor escape from immunosurveillance. By exploring this in a case-control study, our goal was to try and highlight any association of decreased methylation with the carcinogenic process. Indeed, according to the hypothesis of the association with, and role of demethylation of the HLA-G protein on oncogenic progression, our controls were expected to show high HLA-G methylation, and our CIN2/3 cases were expected to show low HLA-G methylation. We did not include CIN1 in our study, as it is less informative given its high rate of

Table 7 Distribution of the study population according to methylation level of the CpG located in the enhancer

\begin{tabular}{|c|c|c|c|c|}
\hline \multirow[t]{3}{*}{$C p G$ (enhancer)* } & \multirow{2}{*}{\multicolumn{2}{|c|}{$\begin{array}{l}\text { Cases } \\
\mathrm{N}=96\end{array}$}} & \multirow{2}{*}{\multicolumn{2}{|c|}{$\begin{array}{c}\text { Controls } \\
\mathrm{N}=76\end{array}$}} \\
\hline & & & & \\
\hline & $\mathrm{N}$ & $\%$ & $\mathrm{~N}$ & $\%$ \\
\hline Mean methylation $<33 \%$ & 37 & 38.5 & 40 & 52.6 \\
\hline Mean methylation $>33 \%$ & 59 & 61.5 & 36 & 47.4 \\
\hline
\end{tabular}

${ }^{*}$ CpG site position 598 (GenBank: J03027.1). spontaneous regression [29-33]. Similarly, a recent publication exploring the association between HLA-G expression and cervical cancer progression also focused on highgrade lesions only [34].

We did not consider invasive cervical cancer in the present study, since the occurrence of HLA-G expression in cervical cancer cells is still controversial in the scientific literature. Some authors reported variable HLA-G expression in cervical cancer cells [15,35,36], others very low or no expression $[37,38]$, suggesting that if methylation status plays a role in promoting carcinogenesis, it probably acts in the early phases, rather than in the advanced phases of the process. For these reasons we focused our investigation on comparing normal cervical cells with high-grade cervical lesions, in which the carcinogenic process, if it has started, is more frequently active.

The HLA-G gene is silenced under physiological conditions independently from proliferative or differentiative status of normal cells $[10,11,39,40]$. Therefore the collection of cervical cells by cytobrush should not have biased the results of our methylation analyses even if many dead epithelial cells were present. As expected, we did find high HLA-G methylation levels in normal cervical cells, which in this context can be considered appropriate controls.

The percentage of $\mathrm{HPV}$-positive $\mathrm{CIN} 2 / 3$ cases was very high, as expected. The low proportion of HPVnegative samples among CIN2/3 cases is consistent with previous reports of HPV DNA-negative CIN2 and CIN3, even though an incorrect histological diagnosis was suspected [41-43]. Among controls, HPV positivity was about $20 \%$, which is in agreement with the mean prevalence described in Brazilian populations (10.4\%-24.5\%) [44]. Frequency analysis of population characteristics and HPV infection were conducted in controls only, as almost all CIN2/3 cases were HPV-positive. This analysis confirmed the risk factors for HPV infection already described in the literature, including young age, low education level, smoking and a higher lifetime number of 
sexual partners. Brazilian Mixed, was the ethnic group that showed the highest prevalence of HPV infection, both in CIN2/3 cases and controls.

The analyses of HPV type distribution in our study population showed a slight increase in the prevalence of some types compared to the distribution that has been previously described in Brazil [24], but were in agreement with the reported prevalence for South America in a worldwide analysis of HPV type distribution [45].

To our knowledge, this is the first study on HLA-G methylation and its association with high-grade cervical lesions. We found a high mean percentage of methylation in both CIN2/3 cases and controls, without substantial differences. This is not in line with data reported for some other cancer types. In ovarian cancer, malignant cells were reported to show higher levels of methylation than normal control cells in some CpG sites, even though expression of the protein did not properly correlate with the methylation status [17]. In renal cancer cells, HLA-G expression via partial de-methylation of its promoter was counted among the strategies used by malignant cells to escape immune response [46]. Indeed HLA-G expression is widely documented in renal cancer cells, while no expression has been reported in normal renal cells [47-49]. Although HLA-G expression has been documented in several other cancer sites, i.e. cervical cancer [15,34-37], melanoma [49-51], breast [49,52-54], colorectal [55-57], gastric [57-60], esophageal $[57,61,62]$, lung $[57,63,64]$, and other cancers $[49]$, the implications of HLA-G methylation on the expression of the protein have not been described.

It has been suggested that even a single CpG dinucleotide could represent a regulatory sequence highly predictive of the explored outcome [65]. Thus we also restricted our association analyses to two specific CpGs that might play a regulatory role, one located in the binding site of transcription factor Sp1, and one in the enhancer region. However, no significant differences were found in methylation between CIN2/3 cases and controls. Evidence of de-methylation events in CIN2/3 cases with respect to controls, which could suggest a reexpression of the HLA-G protein in the cells of cervical high-grade lesions, was not observed. If anything, we found a slight increase in the overall methylation percentage in CIN2/3 cases. This increase was more evident when the analysis was restricted to the CpG located in the enhancer region, specifically when a threshold was set for the methylation level. Although it seems paradoxical, this could be explained by the concomitant global DNA methylation induced by persistent HPV infection [66]. Recent studies have suggested that HPV can modulate DNA methylation patterns in order to control cell proliferation. The oncogenic HPV E7 protein can bind DNA methyltransferases, stimulating their activity [67]. Indeed, many genes have been shown to be hypermethylated in neoplastic cervical lesions [68]. We cannot exclude that the overlap of these hypermethylation events could overshadow low levels of de-methylation in the HLA-G promoter that may be present, or that may occur earlier in the carcinogenesis process. However the impact of low levels of de-methylation is unlikely to be functionally relevant.

Our findings of low HLA-G hypermethylation in CIN2/3 cases also suggested that alterations in methylation can be detected in the cervical samples of subjects with disease despite contamination of the sample by normal cells. This suggests that the results we obtained in our pilot analysis on HLA-G methylation are sufficiently suggestive of the absence of detectable demethylation events in the HLA-G promoter, without requiring an extension of the analyses to the entire study population. Realistically, as has been previously reported, other mechanisms like histone modifications [69], polymorphisms [70] or miRNA [71] may modify HLA-G expression.

We compared population characteristics by HPV status and HLA-G promoter methylation, as some characteristics, including ethnicity, have been reported to affect either one or both of them [72]. If we had found an association, it would have been appropriate to evaluate our results in relation to the demographic and lifestyle characteristics of both cases and controls. However, while we could confirm known associations of some characteristics with HPV infection, we did not find any association with HLA-G methylation; we did not observe significant differences between CIN2/3 cases and controls, nor between HPV-positive and HPV-negative control women.

\section{Conclusions}

This study did not support the hypothesis that spontaneous de-methylation events in the HLA-G promoter play a primary role in the development of precancerous cervical lesions through HLA-G re-expression and consequential promotion of viral and tumor escape from immunosurveillance. Nor was any association found between HLA-G methylation and various demographic and lifestyle factors.

\section{Abbreviations}

Cl: Confidence interval; CIN: Cervical intraepithelial neoplasia; HLA-G: Human leucocyte antigen-G; HPV: Human papillomavirus; LIGH: Laboratory of Immunogenetics and Hystocompatibility; OR: Odds ratio.

\section{Competing interests}

The authors declare no competing interets.

\section{Authors' contributions}

AGT, MGB, VF, LDM, HML, LR and FM participated in the design of the study. MBSX and RS extracted cervical DNA samples. AGT and $V T$ set up the study database. NSC, CAM enrolled study women and provided cytological and histological diagnoses. VT, CG, MT, VF performed molecular analyses. AGT, VF, 
$V T$, LDM interpreted the results. LR, DZ performed statistical analyses. AGT drafted the manuscript. All authors read and approved the final manuscript.

\section{Acknowledgements}

We thank all those in the multidisciplinary group in Curitiba who collaborated in the recruitment of the study population. The study was partially supported by the Alliance FUNPAR-LIGH, the Compagnia di San Paolo/Firms and the Piedmont Region.

\section{Author details}

${ }^{1}$ Department of Medical Sciences, Unit of Cancer Epidemiology - C.E.R.M.S, University of Turin, Turin, Italy. ${ }^{2}$ Laboratory of Immunogenetics and Hystocompatibility, Federal University of Paranà, Curitiba, Brazil. ${ }^{3}$ Department of Gynecology and Obstetrics, Federal University of Paraná, Infectious Diseases in Gynecology and Obstetrics Sector, Hospital de Clínicas, Curitiba, Brazil. ${ }^{4}$ Department of Cervical Pathology, Hospital Erasto Gaertner, Curitiba, Brazil. ${ }^{5}$ Centre for Oncologic Prevention, Turin, Italy.

Received: 10 July 2012 Accepted: 13 December 2012

Published: 24 December 2012

\section{References}

1. Globcan 2008: International Agency for Research on Cancer. [http://globocan.iarc.fr].

2. zur Hausen H: Papillomaviruses-to vaccination and beyond. Biochemistry 2008, 73:498-503.

3. He X, Dong DD, Yie SM, Yang H, Cao M, Ye SR, Li K, Liu J, Chen J: HLA-G expression in human breast cancer: implications for diagnosis and prognosis, and effect on allocytotoxic lymphocyte response after hormone treatment in vitro. Ann Surg Oncol 2010, 17:1459-1469.

4. Maki G, Hayes GM, Naji A, Tyler T, Carosella ED, Rouas-Freiss N, Gregory SA: NK resistance of tumor cells from multiple myeloma and chronic lymphocytic leukemia patients: implication of HLA-G. Leukemia 2008, 22:998-1006.

5. Menier C, Rouas-Freiss N, Carosella ED: The HLA-G non-classical MHC class I molecule is expressed in cancer with poor prognosis. Implications in tumour escape from immune system and clinical applications. Atlas Genet Cytogenet Oncol Haematol 2009, 6:879-900.

6. Jung YW, Kim YT, Kim SW, Kim S, Kim JH, Cho NH, Kim JW: Correlation of human leukocyte antigen-G (HLA-G) expression and disease progression in epithelial ovarian cancer. Reprod Sci 2009, 16:1103-1111.

7. Le Maoult J, Zafaranloo K, Le Danff C, Carosella ED: HLA-G upregulates ILT2, ILT3, ILT4, and KIR2DL4 in antigen presenting cells, NK cells, and T cells. FASEB J 2005, 19:662-664.

8. Clements CS, Kjer-Nielsen L, McCluskey J, Rossjohn J: Structural studies on HLA-G: implications for ligand and receptor binding. Hum Immuno/ 2007, 68:220-6.

9. Hunt JS, Langat DL: HLA-G: a human pregnancy-related immunomodulator. Curr Opin Pharmacol 2009, 9:462-469.

10. Kovats S, Main EK, Librach C, Stubblebine M, Fisher SJ, De Mars R: A class I antigen, HLA-G, expressed in human trophoblasts. Science 1990, 248:220-223.

11. Crisa L, McMaster MT, Ishii JK, Fisher SJ, Salomon DR: Identification of a thymic epithelial cell subset sharing expression of the class Ib HLA-G molecule with fetal trophoblasts. J Exp Med 1997, 186:289-298.

12. Le Discorde M, Moreau P, Sabatier P, Legeais JM, Carosella ED: Expression of HLA-G in human cornea, an immune-privileged tissue. Hum Immunol 2003, 64:1039-1044.

13. Cirulli V, Zalatan J, McMaster M, Prinsen R, Salomon DR, Ricordi C, Torbett BE, Meda P, Crisa L: The class I HLA repertoire of pancreatic islets comprises the nonclassical class lb antigen HLA-G. Diabetes 2006, 55:1214-1222.

14. Lajoie J, Fontaine J, Tremblay C, Routy JP, Poudrier J, Roger M: Persistence of high levels of blood soluble human leukocyte antigen- $G$ is associated with rapid progression of HIV infection. AIDS 2009, 23:1437-1440.

15. Dong DD, Yang $H$, Li $K, X u G$, Song $L H$, Fan $X L$, Jiang $X L$, Yie $S M$ : Human leukocyte antigen-G (HLA-G) expression in cervical lesions: association with cancer progression, HPV 16/18 infection, and host immune response. Reprod Sci 2010, 17:718-723.

16. Deaton $A M$, Bird $A$ : CpG islands and the regulation of transcription. Genes Dev 2011, 25:1010-1022.
17. Menendez L, Walker LD, Matyunina LV, Totten KA, Benigno BB, McDonald JF: Epigenetic changes within the promoter region of the HLA-G gene in ovarian tumors. Mol Cancer 2008, 7:43.

18. Ayres AR, Silva GA: Cervical HPV infection in Brazil: systematic review. Rev Saude Publica 2010, 44:963-974.

19. Holanda F Jr, Castelo A, Veras TM, de Almeida FM, Lins MZ, Dores GB Primary screening for cervical cancer through self sampling. Int J Gynaecol Obstet 2006, 95:179-184.

20. Gakidou E, Nordhagen S, Obermeyer Z: Coverage of cervical cancer screening in 57 countries: low average levels and large inequalities. PLOS Med 2008, 5:e132.

21. Giolo SR, Soler JMP, Greenway SC, Almeida MAA, de Andrade M, Seidman JG, Seidman CE, Krieger JE, Pereir AC: Brazilian urban population genetic structure reveals a high degree of admixture. Eur J Hum Genet 2012, 20:111-116.

22. Dong SM, Pai SI, Rha SH, Hildesheim A, Kurman RJ, Schwartz PE, Mortel R, McGowan L, Greenberg MD, Barnes WA, Sidransky D: Detection and quantitation of human papillomavirus DNA in the plasma of patients with cervical carcinoma. Cancer Epidemiol Biomarkers Prev 2002, 11:3-6.

23. van den Brule AJ, Pol R, Fransen-Daalmeijer N, Schouls LM, Meijer CJ, Snijders PJ: GP5+/6+ PCR followed by reverse line blot analysis enables rapid and high throughput identification of human papillomavirus genotypes. J Clin Microbiol 2002, 40:779-787.

24. WHO/ICO: Human Papillomavirus and Related Cancers. 2010 [www.who.int/ hpvcentre].

25. Sotlar K, Diemer D, Dethleffs A, Hack Y, Stubner A, Vollmer N, Menton S, Menton M, Dietz K, Wallwiener D, Kandolf R, Bültmann B: Detection and typing of human papillomavirus by e6 nested multiplex PCR. J Clin Microbiol 2004, 42:3176-3184.

26. Yoshinouchi M, Hongo A, Nakamura K, Kodama J, Itoh S, Sakai H, Kudo T: Analysis by multiplex PCR of the physical status of human papillomavirus type 16 DNA in cervical cancers. J Clin Microbiol 1999, 37:3514-3517

27. Geraets DT, Heideman DA, de Koning MN, Snijders PJ, Meijer CJ, van Doorn $L$, Quint WG: High genotyping concordance between the Digene HPV Genotyping RH Test and the Reverse Line Blot genotyping assay on GP5 +/6 + -PCR products. J Clin Virol 2009, 46(Suppl 3):S16-S20.

28. Bouvard V, Baan R, Straif K, El Ghissassi F, Benbrahim-Tallaa L, Guha N, Freeman C, Galichet L, Gogliano V, on behalf of the WHO IARC in Cancer Monograph working group: A review of human carcinogens -Part B: biological agents. Lancet Oncol 2009, 10:321-322.

29. Bansal N, Wright JD, Cohen CJ, Herzog TJ: Natural history of established low-grade cervical intraepithelial (CIN 1) lesions. Anticancer Res 2008 28:1763-1766

30. Sastre-Garau X, Cartier I, Jourdan-Da Silva N, De Crémoux P, Lepage $V$, Charron D: Regression of low-grade cervical intraepithelial neoplasia in patients with HLA-DRB1*13 genotype. Obstet Gynecol 2004, 104:751-755.

31. Cox JT, Schiffman M, Solomon D: Prospective follow-up suggests similar risk of subsequent cervical intraepithelial neoplasia grade 2 or 3 among women with cervical intraepithelial neoplasia grade 1 or negative colposcopy and directed biopsy. Am J Obstet Gynecol 2003, 188:1406-1412.

32. Melnikow J, Nuovo J, Willan AR, Chan BK, Howell LP: Natural history of cervical squamous intraepithelial lesions: a meta-analysis. Obstet Gynecol 1998, 92:727-735.

33. Ostor AG: Natural history of cervical intraepithelial neoplasia: a critical review. IntJ Gynecol Pathol 1993, 12:186-192.

34. Li XJ, Zhang $X$, Lin A, Ruan YY, Yan WH: Human leukocyte antigen-G (HLA-G) expression in cervical cancer lesions is associated with disease progression. Hum Immunol 2012, 73:946-949.

35. Rodríguez JA, Galeano L, Palacios DM, Serrano ML, Bravo MM, Combita AL: Altered HLA Class I and HLA-G Expression Is Associated with IL-10 Expression in Patients with Cervical Cancer. Pathobiology 2012, 79:72-83.

36. Zheng N, Wang CX, Zhang $X$, Du LT, Zhang J, Kan SF, Zhu CB, Dong ZG, Wang LL, Wang S, Li W: Up-regulation of HLA-G expression in cervical premalignant and malignant lesions. Tissue Antigens 2011, $77: 218-224$

37. Zhou JH, Ye F, Chen HZ, Zhou CY, Lu WG, Xie X: Altered expression of cellular membrane molecules of HLA-DR, HLA-G and CD99 in cervical intraepithelial neoplasias and invasive squamous cell carcinoma. Life Sci 2006, 78:2643-2649. 
38. Poláková K, Russ G: Expression of the nonclassical HLA-G anti- gen in tumor cell lines is extremely restricted. Neoplasma 2000, 47:342-348.

39. Amiot L, Ferrone S, Grosse-Wilde H, Seliger B: Biology of HLA-G in cancer: a candidate molecule for therapeutic intervention? Cell Mol Life Sci 2011 68:353-368

40. Carosella ED, Favier B, Rouas-Freiss N, Moreau P, LeMaoult J: Beyond the increasing complexity of the immunomodulatory HLA-G molecule. Blood 2008, 111:4862-4870.

41. González-Bosquet E, Esteva C, Muñoz-Almagro C, Ferrer P, Pérez M, Lailla $J M$ : Identification of vaccine human papillomavirus genotypes in squamous intraepithelial lesions (CIN2-3). Gynecol Oncol 2008, 111:9-12.

42. Castle PE, Cox JT, Jeronimo J, Solomon D, Wheeler CM, Gravitt PE, Schiffman $\mathrm{M}$ : An analysis of high-risk human papillomavirus DNA-negative cervical precancers in the ASCUS-LSIL Triage Study (ALTS). Obstet Gynecol 2008, 111:847-856.

43. Sigurdsson K, Taddeo FJ, Benediktsdottir KR, Olafsdottir K, Sigvaldason H, Oddsson K, Rafnar T: HPV genotypes in CIN 2-3 lesions and cervical cancer: a population-based study. Int J Cancer 2007, 121:2682-2687.

44. Roteli-Martins CM, de Carvalho NS, Naud P, Teixeira J, Borba P, Derchain S, Tyring S, Gall S, Diaz A, Blatter M, Shier RM, Romanowski B, Quint WG, Issam J, Galindo C, Schuind A, Dubin G: Prevalence of human papillomavirus infection and associated risk factors in young women in Brazil, Canada, and the United States: a multicenter cross-sectional study. Int J Gynecol Pathol 2011, 30:173-184.

45. Clifford GM, Gallus S, Herrero R, Muñoz N, Snijders PJ, Vaccarella S, Anh PT, Ferreccio C, Hieu NT, Matos E, Molano M, Rajkumar R, Ronco G, de Sanjosé S, Shin HR, Sukvirach S, Thomas JO, Tunsakul S, Meijer CJ, Franceschi S, IARC HPV Prevalence Surveys Study Group: Worldwide distribution of human papillomavirus types in cytologically normal women in the International Agency for Research on Cancer HPV prevalence surveys: a pooled analysis. Lancet 2005, 366:991-998.

46. Seliger B: Immune escape mechanisms of renal cell carcinoma. Eur Urol 2007, 6(Suppl 6):616-622

47. Seliger B, Schlaf G: Structure, expression and function of HLA-G in renal cell carcinoma. Semin Cancer Biol 2007, 17:444-450.

48. Bukur J, Malenica B, Huber C, Seliger B: Altered expression of nonclassical HLA class $1 B$ antigens in hu- man renal cell carcinoma and its association with impaired immune response. Hum Immunol 2003, 64:1081-1092

49. Rouas-Freiss N, Moreau P, Menier C, LeMaoult J, Carosella ED: Expression of tolerogenic HLA-G molecules in cancer prevents antitumor responses. Semin Cancer Biol 2007, 17:413-421.

50. Rebmann V, Wagner S, Grosse-Wilde H: HLA-G expression in malignant melanoma. Semin Cancer Biol 2007, 17:422-429.

51. Paul P, Rouas-Freiss N, Khalil-Daher I, Moreau P, Riteau B, Le Gal FA, Avril MF, Dausset J, Guillet JG, Carosella ED: HLA-G expression in melanoma: a way for tumor cells to escape from immunosurveillance. Proc Natl Acad SCl USA 1998, 95:4510-4515.

52. Dong DD, Yie SM, Li K, Li F, Xu Y, Xu G, Song L, Yang H: Importance of HLA-G expression and tumor infiltrating lymphocytes in molecular subtypes of breast cancer. Hum Immunol 2012, 73:998-1004

53. Provatopoulou X, Kalogera E, Sagkriotis A, Zagouri F, Nonni A, Zografos GC, Gounaris A: Soluble human leukocyte antigen-G expression in patients with ductal and lobular breast malignancy. Anticancer Res 2012, 32:1021-1026.

54. de Kruijf EM, Sajet A, van Nes JG, Natanov R, Putter H, Smit VT, Liefers GJ, van den Elsen PJ, van de Velde CJ, Kuppen PJ: HLA-E and HLA-G expression in classical HLA class I-negative tumors is of prognostic value for clinical outcome of early breast cancer patients. J Immunol 2010, 185:7452-7459.

55. Ye SR, Yang H, Li K, Dong DD, Lin XM, Yie SM: Human leukocyte antigen G expression: as a significant prognostic indicator for patients with colorectal cancer. Mod Pathol 2007, 20:375-383.

56. Zhu CB, Wang CX, Zhang X, Zhang J, Li W: Serum sHLA-G levels: a useful indicator in distinguishing colorectal cancer from benign colorectal diseases. Int J Cancer 2011, 128:617-622.

57. Cao M, Yie SM, Liu J, Ye SR, Xia D, Gao E: Plasma soluble HLA-G is a potential biomarker for diagnosis of colorectal, gastric, esophageal and lung cancer. Tissue Antigens 2011, 78:120-128.

58. Yie SM, Yang H, Ye SR, Li K, Dong DD, Lin XM: Expression of human leukocyte antigen $\mathrm{G}$ (HLA-G) correlates with poor prognosis in gastric carcinoma. Ann Surg Oncol 2007, 14:2721-2729.
59. Du L, Xiao X, Wang C, Zhang X, Zheng N, Wang L, Zhang X, Li W, Wang S, Dong Z: Human leukocyte antigen-G is closely associated with tumor immune escape in gastric cancer by increasing local regulatory T cells. Cancer Sci 2011, 102:1272-1280.

60. Ishigami S, Natsugoe S, Miyazono F, Nakajo A, Tokuda K, Matsumoto M, Okumura H, Douchi T, Hokita S, Aikou T: HLA-G expression in gastric cancer. Anticancer Res 2006, 26:2467-2472.

61. Lin A, Zhang X, Zhou WJ, Ruan YY, Xu DP, Wang Q, Yan WH: Human leukocyte antigen-G expression is associated with a poor prognosis in patients with esophageal squamous cell carcinoma. Int J Cancer 2011, 129:1382-1390.

62. Yie SM, Yang H, Ye SE, Li K, Dong DD, Lin XM: Expression of HLA-G is associated with prognosis in esophageal squamous cell carcinoma. Am J Clin Pathol 2007, 128:1002-1009.

63. Schütt P, Schütt B, Switala M, Bauer S, Stamatis G, Opalka B, Eberhardt W Schuler M, Horn PA, Rebmann V: Prognostic relevance of soluble human leukocyte antigen-G and total human leukocyte antigen class I molecules in lung cancer patients. Hum Immunol 2010, 71:489-495.

64. Yie SM, Yang H, Ye SR, Li K, Dong DD, Lin XM: Expression of human leucocyte antigen $\mathrm{G}$ (HLA-G) is associated with prognosis in non-small cell lung cancer. Lung Cancer 2007, 58:267-274.

65. Claus R, Lucas DM, Stilgenbauer S, Ruppert AS, Yu L, Zucknick M, Mertens D, Bühler A, Oakes CC, Larson RA, Kay NE, Jelinek DF, Kipps TJ, Rassenti LZ, Gribben JG, Döhner H, Heerema NA, Marcucci G, Plass C, Byrd JC: Quantitative DNA methylation analysis identifies a single CpG dinucleotide important for ZAP-70 expression and predictive of prognosis in chronic lymphocytic leukemia. J Clin Oncol 2012, 30:2483-2491.

66. Szalmás A, Kónya J: Epigenetic alterations in cervical carcinogenesis. Semin Cancer Biol 2009, 19:144-152.

67. Burgers WA, Blanchon L, Pradhan S, de Launoit Y, Kouzarides T, Fuks F: Viral oncoproteins target the DNA methyltransferases. Oncogene 2007, 26:1650-1655.

68. Wentzensen N, Sherman ME, Schiffman M, Wang SS: Utility of methylation markers in cervical cancer early detection: appraisal of the state-of-thescience. Gynecol Oncol 2009, 112:293-299.

69. Polakova K, Bandzuchova E, Tirpakova J, Kuba D, Russ G: Modulation of HLA-G expression. Neoplasma 2007, 54:455-462.

70. Castelli EC, Mendes-Junior CT, Veiga-Castelli LC, Roger M, Moreau P, Donadi EA: A comprehensive study of polymorphic sites along the HLA-G gene: implication for gene regulation and evolution. Mol Biol Evol 2011, 28:3069-3086

71. Veit TD, Chies JA: Tolerance versus immune response - microRNAs as important elements in the regulation of the HLA-G gene expression. Transpl Immunol 2009, 20:229-231.

72. Wiley KL, Treadwell E, Manigaba K, Word B, Lyn-Cook BD: Ethnic Differences in DNA Methyltransferases Expression in Patients with Systemic Lupus Erythematosus. J Clin Immunol 2012: . Epub October 9.

doi:10.1186/1471-2407-12-618

Cite this article as: Gillio-Tos et al: Case-control study of HLA-G promoter methylation status, HPV infection and cervical neoplasia in Curitiba, Brazil: a pilot analysis. BMC Cancer 2012 12:618

\section{Submit your next manuscript to BioMed Central and take full advantage of:}

- Convenient online submission

- Thorough peer review

- No space constraints or color figure charges

- Immediate publication on acceptance

- Inclusion in PubMed, CAS, Scopus and Google Scholar

- Research which is freely available for redistribution 